\title{
SECURITY REQUIREMENTS AT THE OLYMPIC GAMES
}

\author{
Violeta Šiljak ${ }^{1}$, Vladan Vukašinović ${ }^{2}$ and Dejan Đurović ${ }^{1}$ \\ ${ }^{1}$ Faculty of Management in sport, Alfa BK University, Serbia \\ ${ }^{2}$ Faculty of Sport and Physical Education University of Belgrade, Serbia
}

\section{Original scientific paper}

\section{SUMMARY}

The subject of this paper is related to the security requirements at the Olympic Games. The Olympic Games are the biggest global sporting event that brings together athletes and spectators from over 200 countries worldwide. The phenomenological aspects of sports - social, political and economic factors are some of the reasons for their planetary popularity. Unfortunately, major events have always attracted the attention of terrorists, various organizations and individuals, who in them saw an opportunity to inhumanely turn the attention to themselves for the sake of objectives that are not associated with sports but rather with politics and other issues. For these reasons the safety requirements of the Olympic Games are very important, and they are among other things one of the primary tasks of the organization of each Olympic Games. The objective of this paper is to emphasize the need and importance of the utilization of security measures during the Olympic Games. In addition to the general safety of all participants and spectators, one should take into account the protection of athletes against injury. For the purpose of providing security for athletes, coaches, managers, delegations, referees, audience and special VIP guests, hosts of the Games take special measures with the help of international assistance. By analyzing commitment of the host cities' Organizational Committees in the $21^{\text {st }}$ century in the field of security, the results of the paper suggest the necessity of the implementation of security measures during the Olympic Games in order to prevent their misuse by negative elements.

Keywords: security measures, terrorism, Olympic Games.

\section{INTRODUCTION}

The Olympic Games have since their creation represented a sporting event that except for sports has had another very important dimension - security. Although the modern Olympic Games were created on the principles of the ancient Olympic Games, today, after 120 years since their restoration, we can begin to recognize their similarities and differences by looking at them from the security aspect. Due to the large number of wars among Greek cities, which resulted in a large number of wounded and dead, which also led to the impoverishment of the cities, on the advice of the oracle of Delphi the ekeheria or sacred truce was established. The agreement that 
was signed on a metal disk by three Greek kings became the basis of the sacred truce among the Greek cities during the Games. In addition to the cessation of wars, this agreement also involved the inviolability of Olympia and immunity of all spectators. Thanks to the sacred truce, all competitors, official representatives of the Greek states and other citizens came, stayed and safely returned to their cities, without fearing something might happen to them on the way. At the beginning of the Games the sacred truce lasted for one month and was later extended to three months and respected by all Greeks as the undisputed law. In addition to extending the duration of the truce, its effect spread to the entire region around Olympia so that the whole of Elis was declared the Holy Land. This included a ban on access to all armed men, as well as all wars.

The truce was upheld for 12 consecutive centuries of the Olympic Games with rare exceptions. Penalties for violators of the truce were very strict. Although the sacred truce did not allow bringing weapons into the Sanctuary during the Games, in 364 B.C. there was a case of a fight in Olympia during the Games (Xenophon, 1988). In an attempt to regain the rule over the Sanctuary, the Eleatics even fought at Altis against Pisano. Later, those Olympic Games did not count like they ever took place.

This useful prophecy used the peace dimension of sports, its ability to transform human aggressiveness into a peaceful competition and at the same time give a chance to the enemies to meet, to fight together and get to know each other in peace at the same stadium. There was also a "real-political" dimension: the best athletes were usually warriors, and therefore it was not possible for them to participate in the Games unless they temporarily stopped fighting. In addition, both athletes and ordinary spectators were forced to travel to Olympia mainly by land (Šiljak, 2013).

However, the human factor as the cause of all the events is the same as three millennia ago. The disputed referee decisions, the use of doping substances in order to win at all costs and amateurism that has grown in professionalism are present at today's Olympic Games, ${ }^{1}$ political boycotts, terrorism, commercialization. These negative situations which the IOC encountered produced its positive reaction in order to preserve the Olympic spirit of the Games; thus very strict security measures are being implemented during the organization of the Games. As a result, a large number of volunteers were included as aid, the Olympic movement for peace was founded in the tradition of the ancient ekeheria, a solidarity fund was established to help athletes, cooperation with the Anti-Doping Agency was realized, and so on (Šiljak, 2013).

The problem of this paper relates to the security of the Games that the organizers face. Security is a very broad term, considering that it can start from the security of the individual to the security of the entire nation or a global sporting event. The development of modern technology

\footnotetext{
${ }^{1}$ One of the five principles based on which the Olympic Games were established in 1894 was that only amateurs could participate in the Games. The interpretation of this principle has in the Olympic history led to unfortunate and unpopular decisions by referees. Modernization of the Games has influenced its change and since 1988 professional athletes have the right to take part in the Games.
} 
provides such equipment for the OC which is based on the latest technology to secure the whole event from unwanted incidents.

The subject of this paper is related to the security requirements at the Olympic Games, the biggest global sporting event. Over the last 120 years of the modern Olympic Games, supporting events have dictated an increase of security measures and consequently an increase in security requirements. The objective of this paper is to emphasize the need to apply security measures during the Olympic Games and prevent their misuse by negative elements.

\section{Modern Olympics and Security}

In addition to its positive side, globalization also has a negative side. Sports, unfortunately, cannot be separated from the impact of economic and political factors, either directly or indirectly and commercialization, professionalism, bidding to host the Olympic Games are all indicators.

Security at the Olympic Games in the beginning of their hosting related mostly to the very actors of the Games; today it has become a much more complex field that entire teams of scientists are dealing with.

World War I prevented the $6^{\text {th }}$ Olympic Games from happening, which were supposed to be held in Berlin in 1916. The organization of the $12^{\text {th }}$ Olympic Games, scheduled for 1940, was entrusted to Tokyo, and after the Second Japanese-Chinese War broke out it was assigned to Helsinki. This competition, was, however, canceled due to World War II, and so were the following Games, which were supposed to be hosted in London in 1944. Due to the safety of participants and spectators, during the $20^{\text {th }}$ century the Games were canceled three times, while the ancient Greeks stopped their wars because of the Games. Nowadays, the IOC is working very hard to revive the institution of the Olympic truce with a very-difficult-to-achieve aim of the cessation of hostilities during all future Olympic Games, as well as after their completion with the final outcome - a peaceful settlement of differences.

With examples of unfortunate events at the Olympic Games in Munich in 1972, Atlanta, 1996, and Athens, 2004, three different ways of jeopardizing security of the Olympic Games can be seen. The Munich Games held from 26 August to 11 September 1972 were the largest held at the time, but they will forever be remembered for the tragic event on 5 September when terrorists, members of the Palestinian organization "Black September", invaded the Olympic Village, and killed two Israeli representatives, and took nine as hostages (figure 1). After an unsuccessful rescue attempt at the Munich airport all hostages were killed, as well as five terrorists and one German police officer. There was a 34-hour interruption of the Games, but after the memorial services to the fallen athletes the Games continued as per the decision of the IOC, with the support of Israeli officials, but with no athletes from that country. 


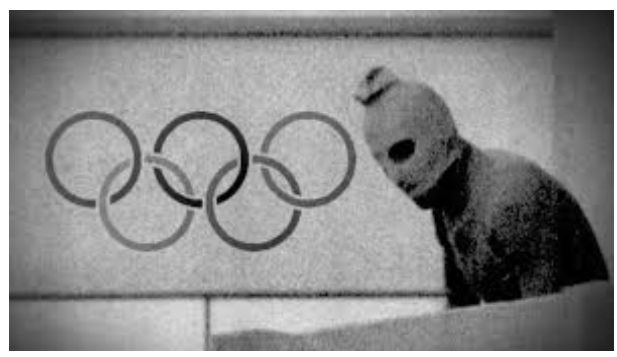

Fig.1 - Palestinian terrorists in Munich in 1972

The act of an organized terrorist attack on Israeli athletes in 1972 in Munich stunned the whole world, and since that day the Games have never been the same. Many countries have during crises like the Cold War boycotted the Olympic Games, while the police and even the army guarded athletes as if they were the most senior political representatives. That's what to a certain extent has managed to prevent any further terrorist attempts at prestigious sporting events.

When a 20-kg bomb exploded at the Olympic Park in 1996 in Atlanta two persons were killed and 111 wounded (Fig. 2). These two lessons are very instructive, especially for the host countries of the Olympic Games. Underestimating such events in the coming period could further aggravate and complicate the security of the Olympic Games.

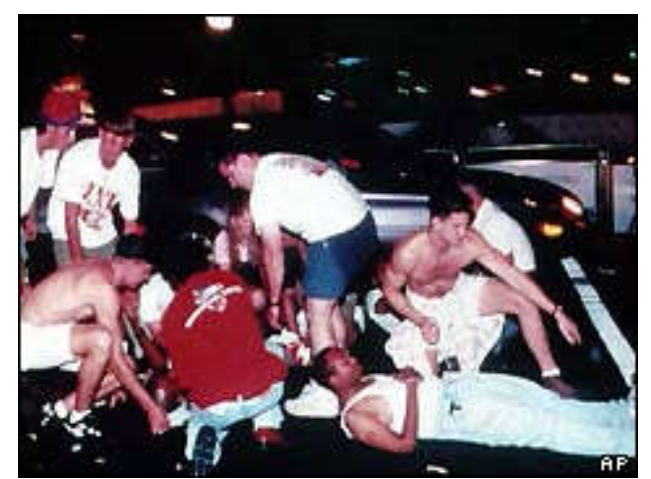

Fig. 2- The victims of the bombing in Atlanta in 1996

A specific attack against a competitor happened in Athens in 2004. During the marathon race, seven kilometers before the finish line, the then-leading Brazilian Vanderlei de Lima was attacked by a spectator, who was later found to be an Irish priest, at a moment when he had an advantage of 48 seconds compared to its closest competitor, and his rhythm was completely interrupted (figure 3). His opponents took advantage of the situation and Italian Stefano Baldini won the gold medal, while Lima came in third. IOC subsequently handed the "Pierre de Coubertin" award to the Brazilian athlete. 


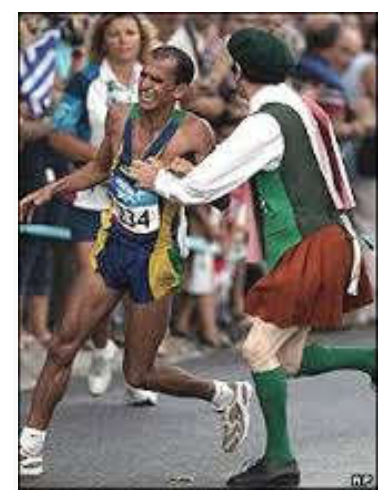

Fig. 3 - The attack on Vanderlei de Lima during the marathon

Although the terrorist attack during the Games in Munich in 1972 was a turning point in the security of this sporting event, a global connection of all security agencies in order to secure the entire event came as late as 2004 and the Athens Olympic Games. However, despite the relatively good security measures in Athens, the previous example indicates that failure is always possible. The Olympic Games have moved the boundaries of sports in many aspects and so caused a clash of different interests, which is the most important argument for emphasizing the issue of security of the Games. Security and sports are two essential elements of every person's life. A man has always aspired to a healthy body and spirit as well as security as a prerequisite to achieve it.

Terrorism today, as a threat to the entire world, including the Olympics, is certainly considered a priority risk, before which all the world's security agencies are teaming up to ensure its prevention. The responsibility of the organizers and the Organizing Committee of the host city is huge and spreads to the whole country, and as such is considered one of their most difficult tasks. However, there are other risks that should be prevented that belong to the field of security management, which is the safety of athletes during the competition. This includes safe sporting facilities, equipment, etc., in relation to the risk of injury of the athletes. If the Winter Olympic Games can be considered safe in terms of terrorist attacks, they can be considered even more dangerous for the lives of the athletes due to their specific sporting tracks and disciplines. Competitions in winter sports border on extreme in terms of difficult trails. A fatal accident that occurred in Vancouver at the Winter Olympics in 2010 confirms this fact. Nodar Kumaritashvili, a Georgian luger, died on the track during training (Fig. 4). The Games had to go on, but the question remains whether the organizers, in order to make the trail more attractive, forgot about its safety. 


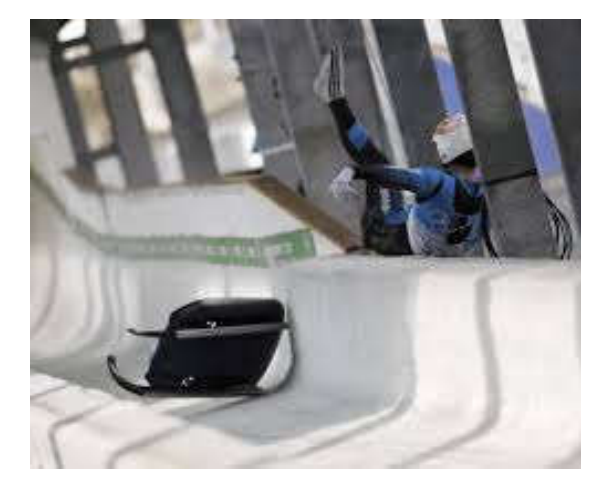

Fig. 4 - Nodar Kumaritashvili immediately after the fatal fall

Russian skier Maria Komissarova suffered a spinal injury after which she was no longer able to walk during the last Winter Olympic Games held in Sochi in 2014. At the Games in Sochi there was the large number of injuries, however, the IOC's official report was the same as from the previous Games in Calgary (http://www.olympic.org/news/ioc-injury-illness-surveillance-studyprotecting-the-athletes-health/225531). It is alleged that the special IOC medical commission followed all competitors during the Games and recorded all injuries. Their further investigation, as well as that of the scientists in the field of medicine should find solutions for safer conditions for competitors. The question is whether doctors can influence a less attractive but a safer trail which, as such, does not please the organizers because it doesn't attract enough attention.

At the Olympic Games 8 athletes have so far lost their lives during the competition (4 at Winter Games and 4 at Summer Games). Outside the competition 14 athletes have lost their lives in various accidents, and out of those 14, 11 were killed in Munich in 1972. There is information about the fallen spectators at the Olympic Games that is not accurate. In Mexico in 1968 a large number of Mexican students who were protesting during the Games were killed; in Atlanta in 1996 a bomb attack killed 2 and injured 111 people, while in London in 2012 two deaths were recorded where a bus ran into a cyclist as it was transporting teams to venues (http://en.wikipedia.org/wiki/Olympic_deaths).

\section{Organization of the Games}

Management of a sporting event is complex because it is necessary to follow the event from the beginning till the end. Olympic Games Management must include all elements of management from planning and organization to management and control, for the successful implementation. Questions of health care and safety at the same time taking into account the potential financial risks are discussed in the framework of a risk management project. In preparing this sporting event the organizer tends to eliminate or reduce to a minimum the events or activities that may disturb the participants of the event (athletes, spectators or officials).

Operational activities related to the organization of the competition include supplying the facility with the necessary equipment, as well as providing all other conditions and operational activities necessary for the successful development of a sporting event: the venue, sports equipment, the 
exact schedule of planned activities, sponsorship, security, crowd control, media and promotional activities, and more.

From an organizational point of view, the Olympic Games represent a major undertaking and challenge for the International Olympic Committee, Organizational Committees, as well as the host city and country. The organization of the Olympic Games is a complex and dynamic process that is constantly changing. Current problems of organization, i.e., management of the Games in general grab the attention of professional and sporting public, and can be found in the sphere of interests of "ordinary" viewers. The organization of the Olympic Games is entrusted by the IOC to the National Olympic Committee of the country of the host city and the host city itself. For this purpose, the NOC has a duty to establish the Organising Committee of the Olympic Games, which from the moment it is constituted reports directly to the Executive Board of the IOC. The Organising Committee of the Olympic Games has the status of a legal entity in the country of the host city. The executive body of the Organizing Committee of the Olympic Games includes: a member of the IOC, the President and the Secretary General of the NOC and at least one member appointed by the host city. It may also include representatives of public authorities and other leading figures. The Organising Committee of the Olympic Games must act in accordance with the Olympic Charter.

Management of the Olympic Games means that future Organising Committees of the Olympic Games start with the candidacy of their city to be the Olympics host city and end by handing in the report to the IOC in the aftermath of the Games (Škaro, 2012). The same author structures the Olympic Games into phases:

- Idea and feasibility

- Competition for project acceptance

- Construction and preparation for the Games

- Hosting the Olympic Games, and

- Closing the Games and using the Olympic legacy.

With the aim of bringing together all competitors, officials and other staff of teams in one place, the Organizing Committee of the Olympic Games must provide the Olympic Village for a period determined by the Executive Board of the IOC. The Olympic Village shall meet all requirements set forth by the Executive Board of the IOC, such as, for example, quotas for the accommodation of delegations of countries.

The Organising Committee of the Olympic Games must provide adequate housing and business premises if certain events occur at a location that is not in the host city of the Games, in accordance with the requirements of the Executive Board of the IOC. Also, it is its duty to organize different events of the cultural program during the entire duration of the Olympic Village. Before its implementation, the cultural program must be submitted for approval to the Executive Board of the IOC. 
In order for, above all, the contestants and then coaches and other members of the delegation to take part in the Olympic Games, they have to respect the Olympic Charter, including the eligibility requirements set forth by the IOC, as well as specific rules of the International Federation.

While organizing the Olympic Games practice has shown that the planned budget for their organization has always been exceeded. Bearing in mind the fact that the number of potential threats to the security of the Games has increased, the cost of their organization has been increasing as well. It is difficult to establish or to get to the official data on how much of that budget is spent on the security segment of the Games, especially if one takes into account the fact that safety concerns not only the participants, but also other persons and objects. Fig. 5 shows the tabulation of resources spent for the organization of the Games in selected examples.

\begin{tabular}{|c|c|c|}
\hline YEAR & HOST CITY & BUDGET \\
\hline 1992 & Barcelona & \$9.3 billion \\
\hline 2002 & Salt Lake City & \$1.2 billion \\
\hline 2004 & Athens & \$9 billion \\
\hline 2010 & Vancouver & \$2.3 billion \\
\hline 2012 & London & \$14.6 billion \\
\hline 2014 & Sochi & \$51 billion \\
\hline
\end{tabular}

Fig. 5 - Tabulation of resources spent for the organization of the Games

If we compare the Games from Salt Lake City and Vancouver, we notice that for the organization of those in Vancouver they spent twice the amount of money. Given that due to the geographical location, natural resources, the number of competitors and visitors the Winter and Summer Olympic Games have not in any way ever been compared, we cannot ignore the fact that until the Olympic Games in Sochi in 2014, figures were in favor of the Summer Olympics. For the overall organization of the Games Russia spent $\$ 51$ billion and thus surpassed all previous costs for the organization of the Games since their beginning to the present. The Russian Federal Security Service engaged four times the number of members of security during the Games than at the Games in London in 2012. In addition, they applied a multiple security system with comprehensive monitoring measures including drones, reconnaissance robots for explosives detection, super-fast boats and submarines that use sonar to detect potential threats coming from the sea (Marković, Draganović \& Radošević, 2014). There is only an assumption how much money went for security, but an example for it can be the cost of the Organizing Committee for the Games in London in 2012 that in addition to the total sum of $\$ 14.6$ billion amounted to approximately $\$ 1$ billion.

In addition to a multi-layered state security body, an Israeli security company is hired for the next Olympic Games to be held in Rio de Janeiro in 2016 at a cost of \$ 2.2 billion. Luiz 
Fernando Correa is the security director of the team of the Organizing Committee of the host, and he coordinated the same tasks during the Pan American Games in Rio in 2007.

\section{Security Requirements at the Olympic Games}

The Organising Committees of the Olympic Games in cooperation with the IOC plan and make documents against which the current preparations for the Olympic Games are conducted, as well as their very implementation.

These official documents are planned in accordance with the place of hosting the Olympic Games and as such contain specific provisions relating to security during the Games. In order to establish the best possible readiness against adverse events, guidelines or priorities will be set up which are considered for possible crisis situations.

On the basis of such document for the Olympic Games held in 2012 in London the security requirements were focused on the following threats:

- terrorism,

- serious crime

- domestic extremism and public disorder, and

- natural disasters.

The document which refers to security for the forthcoming Olympic Games that will be held in Rio de Janeiro in 2016 has seen an increased number of security threat requirements - or has maybe presented them in more detail, namely:

- civil disobedience

- crime

- technological risks

- traffic

- natural disasters

- other disasters

- terrorism

- major traffic accidents, and

- airspace control.

The security team for the Games in London most definitely exercised control of both the airspace and other traffic areas, but it has also singled out four main threats, of which terrorism is the first in significance. It is obvious that the location and environment dictate the priority, and for the upcoming Games civil disobedience and crime are considered a greater threat. The noted examples are the very indicators that general security requirements may be present as well as those specific to every region individually.

In Rio de Janeiro there are ongoing security projects related to the upcoming Games, which relate to: improving supervisory skills, improving the system of training of police forces, 
increasing engagement of civilian police, improving the training of civilian police officers, improving operational management in civilian police, increasing the involvement of the military police, improving criminogenic prevention, and so on. Obviously, such serious projects involve coordination with the intelligence services.

\section{CONCLUSION}

Security during the Olympic Games is nowadays a global project of the Organizing Committee of the Olympic Games, the IOC, the security structures at all levels of the country of the city that is the host of the Olympic Games, as well as the involvement of a large number of world security agencies. The risk can never be eliminated completely, but the potential threats must be identified and understood so they can be mitigated or prevented. Security requirements are not the same for all Olympic Games and they depend on several factors, of which the very location of the Games has the largest role in their planning. Although terrorism is not at the top spot as a threat in the strategy of the forthcoming Olympic Games, it is still considered a global threat to all past Games. Modern technology in the function of intelligence and communications systems, in addition to the above measures so far has confirmed its important role in the effort of the organizers of the Olympic Games to host as safe an event as possible, while further improvement is still needed.

\section{REFERENCES}

1. IOC Injury \& Illness Surveillance Study: protecting the athletes' health, retrived May 10, 2017, from http://www.olympic.org/news/ioc-injury-illness-surveillance-studyprotecting-the-athletes-health/225531

2. Ksenofont. (1988). Helenska istorija [Hellenic History]. Novi Sad, RS: Matica srpska.

3. Marković, J., Draganović, M. \& Radošević, I. (2014). Bezbednosni aspekti Olimpijskih igara kroz istoriju [The security aspect of the Olympic Games through history]. In I. Gajić (Ed.), Prva Međunarodna konferencija "Menadžemnt bezbednosti sportskih takmičenja” (pp. 74-82). Belgrade, RS: Fakultet za sport, Univerzitet "Uniuon-Nikola Tesla.

4. Olympic Deaths. (n.d). Retrieved May 10, 2017, from http://en.wikipedia.org/wiki/Olympic_deaths/

5. Šiljak, V. (2013). Olimpizam [Olympism]. Belgrade, RS: FMS.

6. Škaro, D. (2012). Organizacija Olimpijskih igara [Management of the Olympic Games]. Zagreb, RH: Mate d.o.o.

Received: 28.05.2017.

Accepted: 26.06.2017.

Correspondence author: Violeta Šiljak, PhD

Faculty of Management in sport

Alfa BK University

Palmira Toljatija 3

11070 Novi Beograd, Serbia

violeta.siljak@alfa.edu.rs 